PRINT ISSN 1119-8362

Electronic ISSN 1119-8362
Full-text Available Online at

https://www.ajol.info/index.php/jasem

http://ww.bioline.org.br/ja
J. Appl. Sci. Environ. Manage.

Vol. 25 (3) 377-383 March 2021

\title{
Investigation of the Geochemical Composition and Paleo-Depositional Environment of Ubo and Ikpeshi Marble Deposit, Southwestern Nigeria: A Comparative Study
}

\author{
${ }^{1}$ AILEGBO, J; ${ }^{* 2}$ EHINLAIYE, AO; ${ }^{1}$ BASSEY, P; ${ }^{2}$ ODIA-OSEGHALE, JO \\ ${ }^{* 1}$ Department of Science Laboratory Technology, Faculty of Life Sciences, University of Benin, Benin-City, Edo State, Nigeria \\ ${ }^{* 2}$ Department of Geology, Faculty of Physical Sciences, University of Benin, Benin-City, Edo State, Nigeria \\ *Corresponding Author Email: ayamezimi.ehinlaiye@physci.uniben.edu
}

\begin{abstract}
The marble deposits at Ubo and Ikpeshi areas of Edo state, Southwestern Nigeria, were studied in order to determine the major elements and the paleo-depositional environment of the original sediments using standard methods. Results obtained using test of difference between Ubo and Ikpeshi marbles showed that $\mathrm{CaO}(51.977 \pm 0.922$ \& $54.726 \pm 0.23), \mathrm{MgO}(3.034 \pm 0.829 \& 0.499 \pm 0.115), \mathrm{Na}_{2} \mathrm{O}(1.7 \pm 0.73 \& 0.024 \pm 0.008), \mathrm{MgCO} 3(6.337 \pm 1.734 \&$ $1.034 \pm 0.238), \mathrm{Cu}(24.589 \pm 0.692 \& 27.447 \pm 0.711)$, Ni (23.907 $\pm 0.854 \& 30.979 \pm 0.494)$, all for Ubo and Ikpeshi respectively; with Ni showing highest significance with $\mathrm{P}<0.01$. The Ubo marble deposit occurs as a lensoid body within the younger metasedimentary sequence. The major element composition reveal a mean chemical composition of $\mathrm{CaO}$ (51.97 and $54.73 \%), \mathrm{MgO}(3.0$ and $0.49 \%), \mathrm{SiO}_{2}(0.74$ and $0.70 \%), \mathrm{K}_{2} \mathrm{O}$ (0.08 and $\left.0.04 \%\right), \mathrm{Na}_{2} \mathrm{O}(1.70$ and $0.02 \%), \mathrm{Al}_{2} \mathrm{O}_{3}(0.75$ and $0.25 \%), \mathrm{Fe}_{2} \mathrm{O}_{3}(0.34$ and $0.25 \%$ ), and Loss on Ignition - L.O.I (43.34 and 49.31\%) in Ubo and Ikpeshi marbles respectively, which is indicative that the marble samples were all calcitic. The low values of the total alkali content in the marble samples from the two locations indicate that the environment of deposition of the original carbonate materials that metamorphosed into marbles from both locations must have been a shallow, highly saline environment with probably little influx of salty brine water in the basin. Silica was used as an abscissa in these plots because it shows substantial variations among the marbles with most of the linear relationship between silica and the various oxides showing negative correlation, this probably reflects the admixture of the carbonates with chert. The trend of the plots of $\mathrm{Na}_{2} \mathrm{O}+\mathrm{K}_{2} \mathrm{O}$ vs. $\mathrm{SiO}_{2}$ for the marbles from both locations show a variation in the salinity.
\end{abstract}

DOI: $\underline{\text { https://dx.doi.org/10.4314/jasem.v25i3.11 }}$

Copyright: Copyright (C) 2021 Ailegbo et al. This is an open access article distributed under the Creative Commons Attribution License (CCL), which permits unrestricted use, distribution, and reproduction in any medium, provided the original work is properly cited.

Dates: Received: 12 December 2020; Revised: 26 January 2021; Accepted: 12 February 2021

Keywords: Ubo, Ikpeshi, Marble, Marine Environment, Metasedimentary.

Marble is a major raw material for industries, resulting from the metamorphism of limestone, a carbonate sedimentary rock formed in shallow marine and lakes environment which when subjected to increase in temperature ranging from $150^{\circ} \mathrm{C}-750^{\circ} \mathrm{C}$ and pressure leads to its formation (Mason, 1966) . During recrystallization, the resulting marble rock is typically composed of interlocking grains of crystals with the primary sedimentary structure and texture typically modified. Marble consist of swirls and veins of many coloured varieties which are due to mineral impurities which include quartz, tremolite, actinolite, chert, biotite, muscovite, forsterite, hematite, serpentite, pyrite (Philip et al., 2009). Pure marble (high calcium marble) is composed primarily of the mineral calcite or aragonite with total carbonate content of $95-97 \%$, pure dolomite is composed of $45.7 \% \mathrm{MgCO}_{3}$ and $54.3 \% \mathrm{CaCO}_{3}$ or $30.4 \%$ Lime $(\mathrm{CaO})$ and $21.8 \%$ Magnesia (MgO) (Boynton, 1980). It has been established that various marble deposit such as the Ubo marble, Ukpilla marble etc. are known to occur as lensoid bodies within the younger metasedimentary sequence (Emofurieta and Ekuajemi, 1995). In
"Geochemical investigation of the marble in two outcropping masses of Itobe area of Kogi State (Onimisi et al., 2013), the two masses of marble deposit were deposited in a shallow structural Basin, and mass 1 with a much higher $\mathrm{MgO}$ content $(10.4 \%)$ was deposited in a much deeper Basin than mass 2 with lower $\mathrm{MgO}$ content $(0.74 \%)$. The $\mathrm{Mg}$ in the sample must have been co-precipitated with $\mathrm{Ca}$ from hyper saline water under anoxic condition with microfaunal and flora playing a vital role. In "Geochemical investigation on Albian limestone and marble exposed at Dangote cement quarry near Yandev" (Bolarinwa and Idakwo, 2013 )in order to reconstruct the depositional history of the deposit using major and trace element (Bolarinwa and Idakwo, 2013 ) and observed that from analysis the range of major elements are as follow; $\mathrm{CaO}$ (43.83-53.32), $\mathrm{Al}_{2} \mathrm{O}_{3}$ (0.49-4.02), $\mathrm{Fe}_{2} \mathrm{O}_{3}$ (0.66-2.13), $\mathrm{SiO}_{2}$ (2.1110.00), $\mathrm{MgO}$ (0.44-1.06), and $\mathrm{MnO}$ (0.44-0.97) respectively. Also the trace element contents expressed in ppm were found to be $\mathrm{Sr}$ (340-656), $\mathrm{Ba}$ (14-3821), Zr (8-232) Rb (5-49), Cr (5-121), Pb (2$15), \mathrm{Zn}$ (7-72). Interpretation of the result suggest a 
shallow marine possibly an off-shelf depositional model for the deposit. In "Petrogenetic and distribution of trace and rare elements in the marble from Igarra Area, Southwestern Nigeria" (Obasi and Ogungbuyi, 2013) determined the multivariate statistical analysis and upper background methods and used them to interpret geochemical data of the trace and rare elements in the marble from Igarra in order to determine the provenance and elemental mineralized anomalies. Results showed that the trace elements are within the background values except elements $\mathrm{Ba}, \mathrm{Sr}$ and $\mathrm{Zr}$ whose contents in some samples exceed the upper background threshold of $68.77 \mathrm{ppm}$, and 14.13 ppm, respectively. Geochemical data revealed a depleted concentration of the heavy rare elements, Eu (0.04-0.17 ppm), Tb (0.01-0.2 ppm), Er (0.09-0.7 ppm) and Lu (0.03-0.1) and an enriched light rare earth elements, (LREE), La (0.8-10 ppm), Na (0.5-4.3 ppm). In "Geochemistry and economic potential of calcgneiss and marble from Igarra, Edo State," (Obasi, 2012). Carried out geochemical and physical analysis on carbonate rocks and observed that these samples were low in $\mathrm{SiO}_{2}\left(1.8-4.83\right.$ wt \%), $\mathrm{Al}_{2} \mathrm{O}_{3}$ (0.6-0.6 wt $\%), \quad \mathrm{MgO}(1.10-5.33 \mathrm{wt} \%)$, relatively high to medium $\mathrm{CaO}$ (46.51-53.06wt\%), low dolomite $\mathrm{CaMg}\left(\mathrm{CO}_{3}\right)_{2}(2.30-11.14 \mathrm{wt} \%)$ and the corresponding $\mathrm{CaCO}_{3}$ (85-94.68 wt\%). Physical test showed that these samples have high compressive and tensile strength which are expression of their durability and hardness potential.

\section{MATERIALS AND METHODS}

Description of the Study Area: The study area Ubo and Ikpeshi belongs to the Southern basement complex of Nigeria which is underlain by metasediment. (Madhavaraju and Rahmasamy, 1999). This study was carried out to characterize the marble deposits of Ubo and Ikpeshi with the aim of geochemically deciphering the major element of the marble samples. The study area is located in Ubo and Ikpeshi, Southwestern Nigeria and lies between latitude N07 $8^{\prime} 47^{\prime \prime}$ - N07 25 $18^{\prime \prime}$ and longitude E06 $1054-$ E06 $^{\circ} 24^{\prime} 35^{\prime \prime}$ of Auchi Sheet 266 on a scale of $1: 10,000$ with an area extent of $420.86 \mathrm{~km}$. Marble is found in the North- Eastern part of the area and active quarries are observed in many parts (Fig 1). The study area lies within the tropical climate. It is characterized by two seasons, the Wet season (between April-October) and the Dry season (November - March) with a mean annual rainfall of $1250 \mathrm{~mm}$ and a temperature range of 20 to $38^{\circ} \mathrm{C}$. Ubo and Ikpeshi marble falls within the savannah belt. These areas are characterized with thick vegetation; tall canopied trees, shrubs and green grasses. The climate and topography play an important role in the vegetation of the area. The vegetation is more dense in low-lying areas and sparse in the upland area due to abundant runoffs from crystalline rocks.

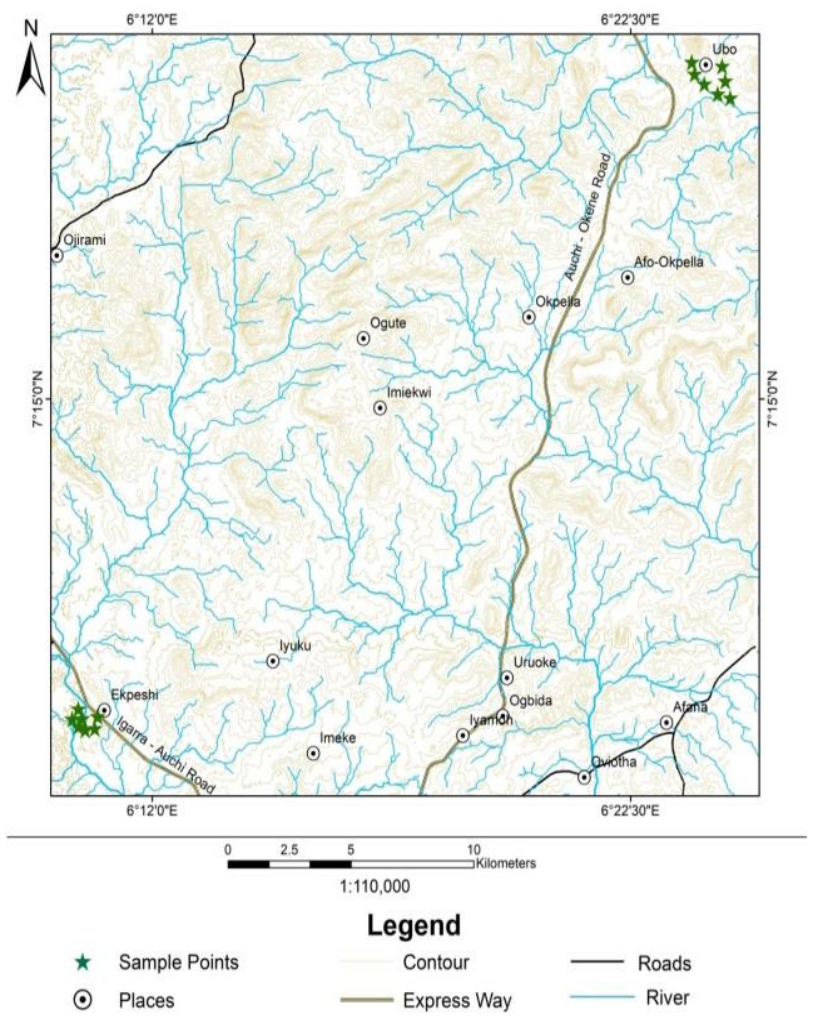

Fig 1: Map of Study Area Showing Sample Location

The study area, Ubo and Ikpeshi is an area with accessibility moderate in some areas and quite difficult in some areas because of the thick bushes and trees and the break of slopes between lowland and hills. The area is essentially made up of basement rocks and thus has a very rough and rugged topography.

Methodology: The field survey involves going to the field, observing various outcrop in situ. The field work was carried out in Ubo and Ikpeshi area with samples obtained in locations that exposed surface outcrops. Fourteen (14) samples were collected, seven (7) each from the different locations of the study area.

Laboratory Analysis: Fourteen (14) samples were analyzed using XRF (X-Ray Fluorescence) equipment (Phillips P.W., 1800) for the major oxides and trace element, in Rohab Laboratory Ibadan, Oyo State.

\section{RESULTS AND DISCUSSION}

The results from the XRF analysis from Ubo and Ikpeshi marbles, the comparison of the chemical composition with typical calcitic and dolomitic marbles, the correlation matrix and the descriptive analysis are shown in table 1-8, respectively. 
Investigation of the Geochemical Composition.....

Table 1: Results obtained from the geochemical analysis of the marble in Ubo (wt\% of oxide)

\begin{tabular}{|c|c|c|c|c|c|c|c|c|c|c|c|c|c|c|c|}
\hline Sample & $\mathrm{SiO}_{2}$ & $\mathrm{Al}_{2} \mathrm{O}_{3}$ & $\mathrm{Fe}_{2} \mathrm{O}_{3}$ & $\mathrm{CaO}$ & $\mathrm{MgO}$ & $\mathrm{K}_{2} \mathrm{O}$ & $\mathrm{Na}_{2} \mathrm{O}$ & $\mathrm{CaCO}_{3}$ & $\mathrm{MgCO}_{3}$ & $\mathrm{Cr}$ & $\mathrm{Ba}$ & $\mathrm{Cu}$ & $\mathrm{Ni}$ & LOI & T. Alkalis \\
\hline 1 & 0.18 & 0.46 & 0.04 & 51.18 & 2.34 & - & 3.40 & 91.10 & 4.89 & 114.21 & 460.26 & 22.25 & 22.23 & 42.39 & 3.40 \\
\hline 2 & 0.90 & 0.71 & 0.09 & 48.50 & 2.79 & 0.10 & 4.45 & 86.33 & 5.83 & 113.22 & 422.39 & 23.32 & 24.45 & 42.5 & 4.55 \\
\hline 3 & 1.06 & 0.82 & 0.15 & 49.94 & 2.71 & 0.07 & 3.33 & 88.89 & 5.66 & 114.22 & 266.18 & 26.38 & 26.62 & 41.9 & 3.40 \\
\hline 4 & 0.07 & 0.25 & 0.05 & 55.90 & 3.11 & 0.04 & 0.31 & 99.50 & 6.49 & 120.34 & 637.29 & 23.33 & 22.61 & 45.7 & 0.35 \\
\hline 5 & 1.18 & 0.08 & 0.07 & 53.64 & 1.75 & 0.02 & 0.01 & 95.47 & 3.65 & 132.46 & 673.21 & 27.36 & 20.52 & 42.6 & 0.03 \\
\hline 6 & 1.47 & 0.78 & 0.11 & 52.80 & 0.84 & 0.07 & 0.12 & 93.98 & 1.75 & 102.24 & 668.27 & 25.25 & 24.42 & 43.5 & 0.19 \\
\hline 7 & 0.37 & 2.18 & 1.92 & 51.88 & 7.70 & 0.19 & 0.28 & 92.34 & 16.09 & 104.21 & 552.33 & 24.23 & 26.50 & 43.6 & 0.47 \\
\hline Mean & 0.74 & 0.75 & 0.34 & 51.97 & 3.0 & 0.07 & 1.94 & 92.51 & 6.33 & 114.4 & 525.52 & 23.55 & 23.65 & 3.34 & 1.77 \\
\hline
\end{tabular}

Table 2: Results obtained from the geochemical analysis of the marble in Ikpeshi(wt\% of oxide)

\begin{tabular}{|c|c|c|c|c|c|c|c|c|c|c|c|c|c|c|c|}
\hline Sample & $\mathrm{SiO}_{2}$ & $\mathrm{Al}_{2} \mathrm{O}_{3}$ & $\mathrm{Fe}_{2} \mathrm{O}_{3}$ & $\mathrm{CaO}$ & $\mathrm{MgO}$ & $\mathrm{K}_{2} \mathrm{O}$ & $\mathrm{Na}_{2} \mathrm{O}$ & $\mathrm{CaCO}_{3}$ & $\mathrm{MgCO}_{3}$ & $\mathrm{Cr}$ & $\mathrm{Ba}$ & $\mathrm{Cu}$ & $\mathrm{Ni}$ & LOI & T.Alkalis \\
\hline 1 & 0.71 & 0.52 & 0.34 & 54.75 & 0.35 & 0.01 & 0.01 & 97.45 & 0.73 & 120.2 & 420.57 & 28.24 & 28.45 & 42.01 & 0.02 \\
\hline 2 & 0.9 & 0.07 & 0.18 & 54.01 & 0.42 & 0.08 & 0.02 & 96.13 & 0.87 & 110.22 & 472.6 & 27.35 & 30.6 & 43.72 & 0.10 \\
\hline 3 & 0.2 & 0.1 & - & 55.8 & 1.18 & - & 0.07 & 99.32 & 2.45 & 112.2 & 266.67 & 28.36 & 31.65 & 42.55 & 0.07 \\
\hline 4 & 0.91 & 0.06 & 0.18 & 54.04 & 0.44 & 0.09 & 0.02 & 96.19 & 0.91 & 100.3 & 637.61 & 28.33 & 31.6 & 44.2 & 0.11 \\
\hline 5 & 0.74 & 0.5 & 0.33 & 54.72 & 0.35 & 0.02 & 0.02 & 97.40 & 0.73 & 112.4 & 643.62 & 28.33 & 32.55 & 42.12 & 0.04 \\
\hline 6 & 0.88 & 0.06 & 0.21 & 55.01 & 0.42 & 0.09 & 0.01 & 97.91 & 0.87 & 114.2 & 658.63 & 28.26 & 31.45 & 44.1 & 0.10 \\
\hline 7 & 0.76 & 0.48 & 0.3 & 54.75 & 0.33 & 0.02 & 0.02 & 97.45 & 0.68 & 110.22 & 542.86 & 23.26 & 30.55 & 42.4 & 0.04 \\
\hline Mean & 0.7 & 0.25 & 0.25 & 54.73 & 0.49 & 0.04 & 0.02 & 97.40 & 1.03 & 111.39 & 520.36 & 27.22 & 30.97 & 49.31 & 0.07 \\
\hline
\end{tabular}

Table 3: A Comparison of the Chemical Composition of Ubo and Ikpeshi Marble with Typical Calcitic and Dolomitic Marbles

\begin{tabular}{|c|c|c|c|c|c|c|c|c|c|c|}
\hline & \multicolumn{5}{|c|}{$\begin{array}{l}\text { Group A } \\
\text { Typical Calcitic marbles }\end{array}$} & \multicolumn{2}{|c|}{$\begin{array}{l}\text { This study } \\
\text { Ubo Ikpeshi }\end{array}$} & \multicolumn{3}{|c|}{$\begin{array}{l}\text { Group C } \\
\text { Typical dolomitic marbles }\end{array}$} \\
\hline & 1 & 2 & 3 & 4 & 5 & 6 & 7 & 8 & 9 & 10 \\
\hline $\mathrm{SiO}_{2}$ & 0.71 & 0.90 & 1.18 & 0.25 & 11.92 & 0.74 & 0.72 & 0.49 & 2.40 & 1.98 \\
\hline $\mathrm{TiO}_{2}$ & n.d & 0.02 & - & n.d & 0.13 & - & - & n.d & 0.01 & 0.01 \\
\hline $\mathrm{A}_{2}{ }_{2} \mathrm{O}_{3}$ & 0.52 & 0.07 & 0.08 & 0.35 & 2.39 & 0.75 & 0.25 & 0.02 & 0.92 & 0.013 \\
\hline $\mathrm{Fe}_{2} \mathrm{O}_{3}$ & 0.34 & 0.18 & 0.07 & - & 1.04 & 0.34 & 0.25 & 0.06 & 0.04 & 0.36 \\
\hline $\mathrm{MnO}$ & - & - & 0.03 & - & 0.03 & - & - & 0.03 & 0.009 & 0.03 \\
\hline $\mathrm{MgO}$ & 0.35 & 0.42 & 1.75 & 0.15 & 0.67 & 3.0 & 0.49 & 20.70 & 19.60 & 20.84 \\
\hline $\mathrm{CaO}$ & 54.75 & 54.01 & 53.64 & 56.12 & 45.00 & 51.97 & 54.73 & 28.94 & 31.82 & 31.04 \\
\hline $\mathrm{Na}_{2} \mathrm{O}$ & 0.01 & 0.02 & 0.01 & 0.01 & 0.39 & 1.7 & 0.02 & 0.01 & 0.05 & n.d \\
\hline $\mathrm{K}_{2} \mathrm{O}$ & 0.01 & 0.08 & 0.02 & 0.03 & 0.70 & 0.08 & 0.04 & 0.01 & 0.007 & 0.07 \\
\hline $\mathrm{P}_{2} \mathrm{O}_{5}$ & - & 0.02 & - & - & - & $\mathrm{Tr}$ & - & n.d & 0.045 & n.d \\
\hline $\mathrm{CaCO} 3$ & 97.71 & - & 95.72 & - & - & 92.51 & 97.40 & 51.69 & - & - \\
\hline $\mathrm{MgCO} 3$ & 0.78 & - & 3.67 & - & - & 6.33 & 1.03 & 43.34 & 44.09 & - \\
\hline L.O.I & 42.01 & 4.072 & - & - & - & 43.34 & 49.31 & - & - & - \\
\hline
\end{tabular}

n.d- Not detected; Tr-Trace amount; 1. Shapfell marble (Howrie et al, 1982), 2. Jakura marble (Okunlola, 2001), 3. Ososo marble (Emuforieta et al, 1990), 4. Mfamosing limestone (Dada, 1993), 5. Zambezi belt marble (Munyanyiwa and Hanson, 1988), 6. Ubo marble (This study), 7. Ikpeshi marble (This study), 8. Muro hill marble (Tegure, 1989), 9. Igbeti marble (Emuforieta et al, 1990); 10. FCT, Abuja marble (Davou and Ashano, 2009)

\begin{tabular}{|c|c|c|c|}
\hline & $\begin{array}{l}\text { Ubo Marble } \\
\text { Mean } \pm \text { SE }\end{array}$ & $\begin{array}{l}\text { Ikpeshi Marble } \\
\text { Mean } \pm \text { SE }\end{array}$ & P-Value \\
\hline $\mathrm{SiO}_{2}$ & $0.747 \pm 0.204$ & $0.729 \pm 0.093$ & $\mathrm{P}>0.05$ \\
\hline $\mathrm{Al}_{2} \mathrm{O}_{3}$ & $0.754 \pm 0.26$ & $0.256 \pm 0.087$ & $\mathrm{P}>0.05$ \\
\hline $\mathrm{Fe}_{2} \mathrm{O}_{3}$ & $0.347 \pm 0.263$ & $0.22 \pm 0.045$ & $\mathrm{P}>0.05$ \\
\hline $\mathrm{CaO}$ & $51.977 \pm 0.922$ & $54.726 \pm 0.23$ & $* \mathbf{P}<\mathbf{0 . 0 5}$ \\
\hline $\mathrm{MgO}$ & $3.034 \pm 0.829$ & $0.499 \pm 0.115$ & $* \mathbf{P}<\mathbf{0 . 0 5}$ \\
\hline $\mathrm{K}_{2} \mathrm{O}$ & $0.07 \pm 0.024$ & $0.044 \pm 0.015$ & $\mathrm{P}>0.05$ \\
\hline $\mathrm{Na}_{2} \mathrm{O}$ & $1.7 \pm 0.73$ & $0.024 \pm 0.008$ & $* \mathbf{P}<0.05$ \\
\hline $\mathrm{CaCO}_{3}$ & $92.516 \pm 1.641$ & $97.407 \pm 0.409$ & $\mathrm{P}>0.05$ \\
\hline $\mathrm{MgCO}_{3}$ & $6.337 \pm 1.734$ & $1.034 \pm 0.238$ & $* \mathbf{P}<0.05$ \\
\hline $\mathrm{Cr}$ & $114.414 \pm 3.825$ & $111.391 \pm 2.252$ & $\mathrm{P}>0.05$ \\
\hline $\mathrm{Ba}$ & $525.704 \pm 57.228$ & $520.366 \pm 54.59$ & $P>0.05$ \\
\hline $\mathrm{Cu}$ & $24.589 \pm 0.692$ & $27.447 \pm 0.711$ & $* \mathbf{P}<0.05$ \\
\hline $\mathrm{Ni}$ & $23.907 \pm 0.854$ & $30.979 \pm 0.494$ & $* * \mathbf{P}<\mathbf{0 . 0 1}$ \\
\hline LOI & $43.17 \pm 0.48$ & $43.014 \pm 0.361$ & $* \mathbf{P}<0.05$ \\
\hline
\end{tabular}

Variation Diagram: A series of major element oxide plots for the Ikpeshi and Ubo marble is presented in figure 2-10. Plots of selected major oxides were carried out for the marble deposit. Silica was used as an abscissa in these plots because it shows substantial variations among the marbles with most of the linear relationship between silica and the various oxides showing negative correlation. Coefficient close to either -1 or +1 shows strong relationship which indicates dependency (Onimisi et al., 2013). These relationships are shown in Tables 2 to 12 
.Table 5: Correlation coefficient matrix of oxides in marble samples from Ubo

\begin{tabular}{|c|c|c|c|c|c|c|c|}
\hline & $\mathrm{SiO}_{2}$ & $\mathrm{Al}_{2} \mathrm{O}_{3}$ & $\mathrm{Fe}_{2} \mathrm{O}_{3}$ & $\mathrm{CaO}$ & $\mathrm{MgO}$ & $\mathrm{K}_{2} \mathrm{O}$ & $\mathrm{Na}_{2} \mathrm{O}$ \\
\hline $\mathrm{SiO}_{2}$ & 1 & & & & & & \\
\hline $\mathrm{Al}_{2} \mathrm{O}_{3}$ & -.130 & 1 & & & & & \\
\hline $\mathrm{Fe}_{2} \mathrm{O}_{3}$ & -.271 & $.929^{* *}$ & 1 & & & & \\
\hline $\mathrm{CaO}$ & -.255 & -.294 & -.043 & 1 & & & \\
\hline $\mathrm{MgO}$ & -.520 & $.842^{* *}$ & $.933^{* *}$ & -.063 & 1 & & \\
\hline $\mathrm{K}_{2} \mathrm{O}$ & -.011 & $.925^{* *}$ & $.862^{* *}$ & -.284 & $.803^{*}$ & 1 & \\
\hline $\mathrm{Na}_{2} \mathrm{O}$ & -.069 & -.093 & -.314 & $-.836^{* *}$ & -.137 & -.111 & 1 \\
\hline
\end{tabular}

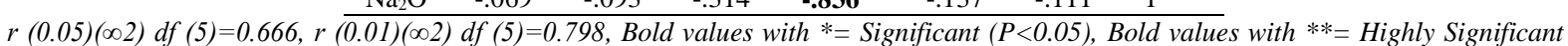
$(P<0.01)$

Table 6: Correlation coefficient matrix of oxides in marble samples from Ikpeshi

\begin{tabular}{llllllll}
\hline & $\mathrm{SiO}_{2}$ & $\mathrm{Al}_{2} \mathrm{O}_{3}$ & $\mathrm{Fe}_{2} \mathrm{O}_{3}$ & $\mathrm{CaO}$ & $\mathrm{MgO}$ & $\mathrm{K}_{2} \mathrm{O}$ & $\begin{array}{l}\mathrm{Na}_{2} \\
\mathrm{O}\end{array}$ \\
\hline $\mathrm{SiO}_{2}$ & 1 & & & & & & \\
$\mathrm{Al}_{2} \mathrm{O}_{3}$ & -.029 & 1 & & & & & \\
$\mathrm{Fe}_{2} \mathrm{O}_{3}$ & .581 & $.784^{*}$ & 1 & & & & \\
$\mathrm{CaO}$ & $\mathbf{8 5 6}^{* *}$ & .065 & -.413 & 1 & & & \\
$\mathrm{MgO}$ & $\mathbf{8 9 0}^{* *}$ & -.427 & $\mathbf{8 8 5}^{* *}$ & $\mathbf{. 7 2 2}^{*}$ & 1 & & \\
$\mathrm{~K} \mathrm{O}$ & $\mathbf{. 7 4 1}^{*}$ & $\mathbf{. 6 8 6}^{*}$ & -.094 & -.630 & -.360 & 1 & \\
$\mathrm{Na}_{2} \mathrm{O}$ & $\mathbf{9 0 5}^{* *}$ & -.298 & $\mathbf{- . 8 2 0}^{*}$ & $\mathbf{. 6 7 0}^{*}$ & $\mathbf{. 9 6 4}^{* *}$ & -.465 & 1 \\
\hline
\end{tabular}

$r(0.05)(\infty 2) d f(5)=0.666 ; r(0.01)(\infty 2) d f(5)=0.798 ;$ Bold values with $*=$ Significant $(P<0.05) ;$ Bold values with $* *=$ Highly Significant

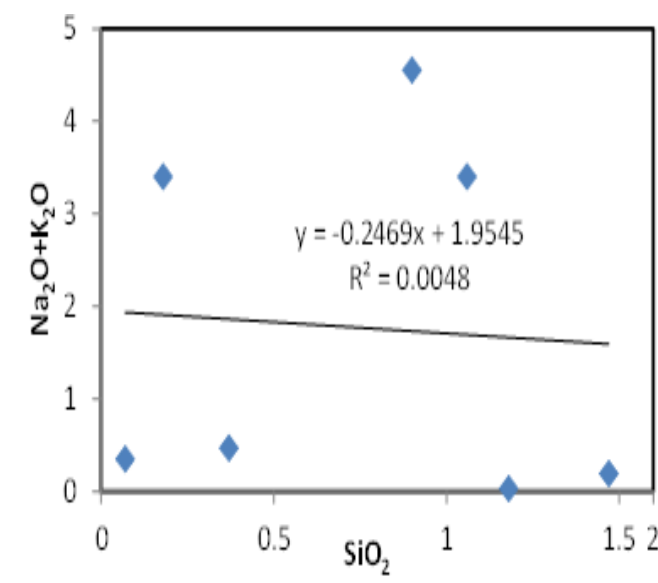

Fig 2: Plot of wt $\%$ of $\mathrm{Na} 2 \mathrm{O}+\mathrm{K}_{2} \mathrm{O}$ vs. wt $\%$ of $\mathrm{SiO}_{2}$ for $\mathrm{Ubo}$ Marble

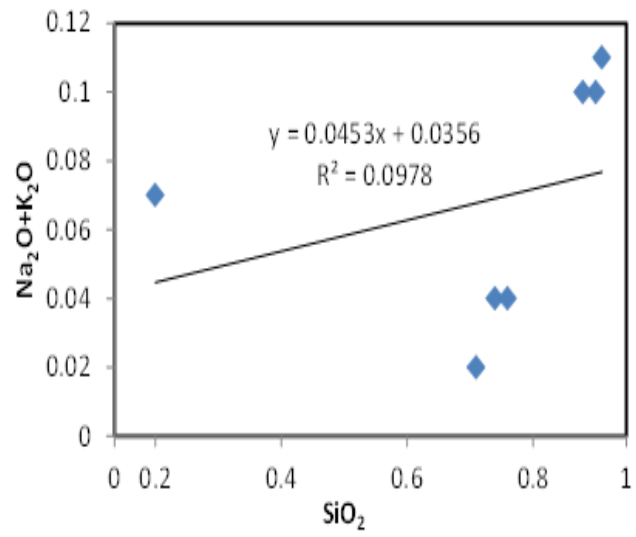

Fig 3: Plot of wt $\%$ of $\mathrm{Na}_{2} \mathrm{O}+\mathrm{K}_{2} \mathrm{O}$ vs. wt $\%$ of $\mathrm{SiO}_{2}$ for Ikpeshi Marble

According to Land and Hopp, (1973). Alkalis are indicative of salinity levels and is useful in interpreting depositional and lithification conditions prior to $(P<0.01)$

metamorphism of carbonate rocks. The concentration of the total alkalis in the studied samples is low, which indicates that the environment of deposition of the marble was probably a shallow, saline environment.

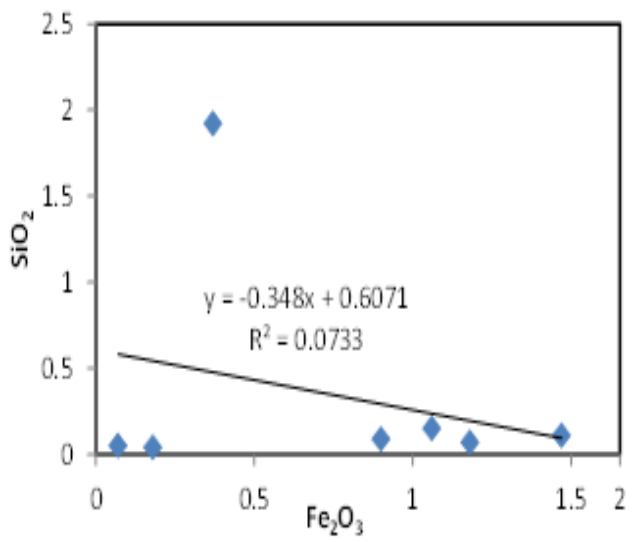

Fig 4: Plot of wt $\%$ of $\mathrm{SiO}_{2}$ vs. wt $\%$ of $\mathrm{Fe}_{2} \mathrm{O}_{3}$ for Ubo Marble

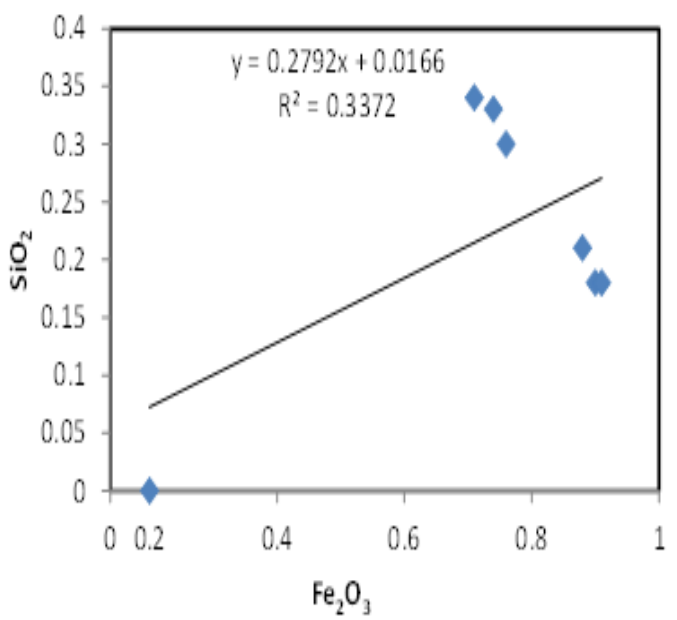

Fig 5: Plot of wt $\%$ of $\mathrm{SiO}_{2}$ vs. wt $\%$ of $\mathrm{Fe}_{2} \mathrm{O}_{3}$ for Ikpeshi Marble 
The above diagram shows a weak and strong negative downhill linear relationship between the two variables. Decrease in silica content leads to an increase in iron oxide during deposition of the parent rock. In other words, the variables move in an opposite direction which indicates deep shallow marine environment. Presence of $\mathrm{Fe}_{2} \mathrm{O}_{3}$ indicates an oxidizing environment. During influx of continental sediment into the ocean, free oxygen in shallow environment tend to oxidize the iron content leading to faster precipitation of iron content (insoluble in sea water) relative to silica (Clarke, 1924).

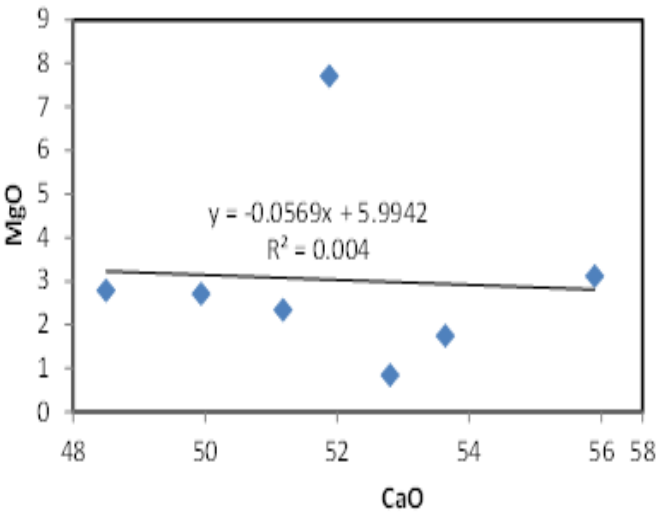

Fig 6: Plot of wt $\%$ of $\mathrm{MgO}$ vs. wt $\%$ of $\mathrm{CaO}$ for Ubo Marble

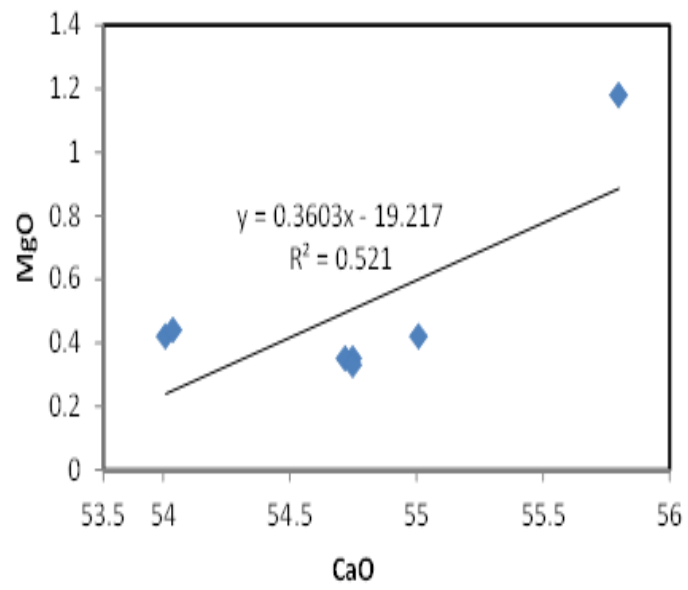

Fig 7: Plot of wt $\%$ of $\mathrm{MgO}$ vs. wt $\%$ of $\mathrm{CaO}$ for Ikpeshi Marble

This is a positive linear relationship between the two variables which signifies increase in one variable during deposition leads to increase in the other variable which could be attributed to their similar electronic structure and chemical reaction. The geochemical cycle between the two oxide are similar except for the variation brought about by the difference in solubility between the two compounds. The lower solubility of $\mathrm{CaO}$ as compared to $\mathrm{MgO}$ may have lead to extensive precipitation of calcite as compared to higher solubility of $\mathrm{MgO}$ with small amount precipitation of dolomite as seen in Table 1 and 2 (Chave, 1954). The residence time of magnesium in the ocean is $15 \times 10^{6}$ years and that of calcium is $1 \times 10^{6}$ years which also reflect the lower solubility.

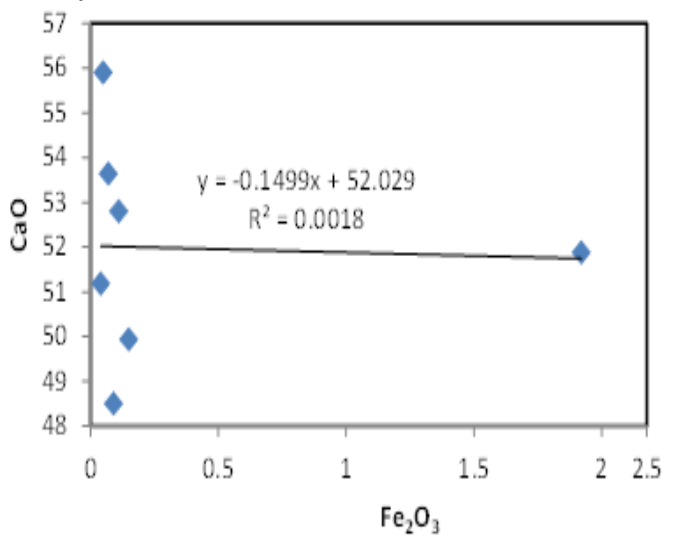

Fig 8: Plot of wt $\%$ of $\mathrm{CaO}$ vs. wt $\%$ of $\mathrm{Fe}_{2} \mathrm{O}_{3}$ for Ubo Marble

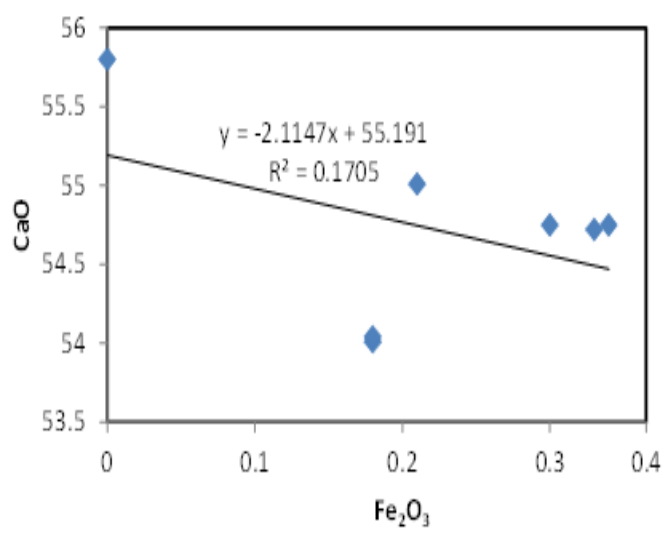

Fig 9: Plot of wt $\%$ of $\mathrm{CaO}$ vs. wt $\%$ of $\mathrm{Fe}_{2} \mathrm{O}_{3}$ for Ikpeshi Marble

The above diagram shows a weak downhill negative and strong uphill positive linear relationship. The relationship of iron content with the $\mathrm{CaO}$ could be attributed to weathering of the rock or presence of clay minerals coexisting with the rock (Fruth, 1986).

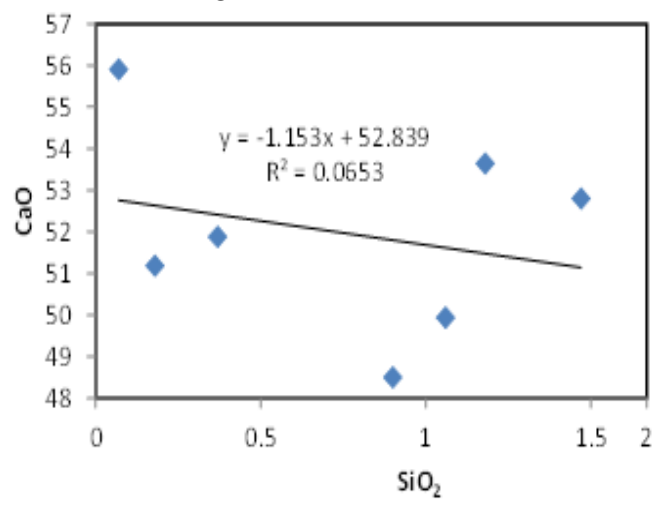

Fig 10: Plot of wt $\%$ of $\mathrm{CaO}$ vs. wt $\%$ of $\mathrm{SiO}_{2}$ for Ubo Marble

The above diagram shows a downhill relationship between the two variables which probably indicates 
that during deposition of the parent marble body as $\mathrm{CaO}$ increases silica decreases for both Marble. The silica would have been precipitated from hot brine flux in deep Basin or from low input of deltaic influx from nearby source due to climate change with high precipitation of calcite from dissolve material, transported from previously deposited biogenic material. (Dunham, 1962).

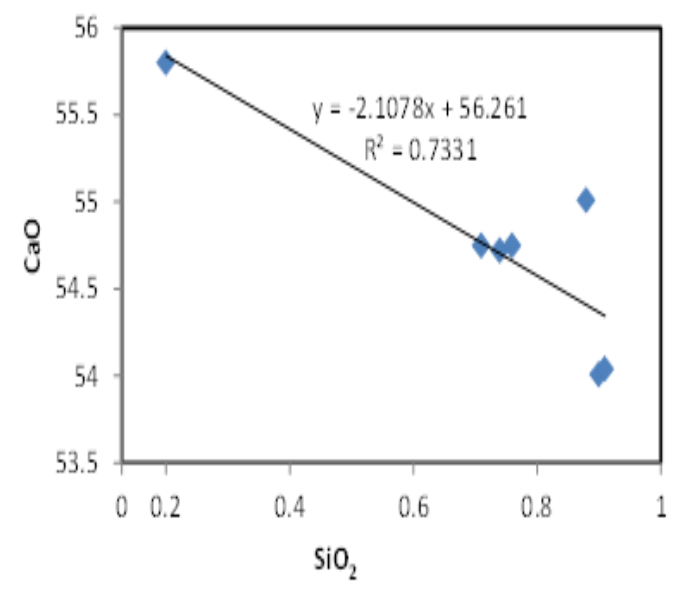

Fig 11. Plot of wt $\%$ of $\mathrm{CaO}$ vs. wt $\%$ of $\mathrm{SiO}_{2}$ for Ikpeshi Marble

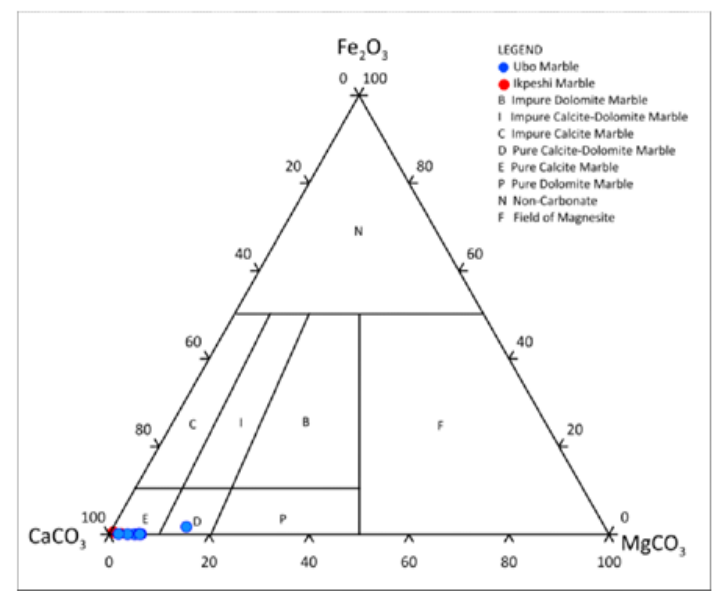

Fig 12: Classification of the Ubo and Ikpeshi Marble (After Carr \& Rooney, 1983)

Percentage of $\mathrm{CaCO}_{3}$ and $\mathrm{MgCO}_{3}$ : Pure carbonates are believed to have a total carbonate content $\left(\mathrm{CaCO}_{3}\right)$ or $\mathrm{CaMg}\left(\mathrm{CO}_{3}\right)_{2}$ of $70 \%$ and above while impure carbonates have between $40-70 \%$. Other oxides like $\mathrm{SiO}_{2}, \mathrm{TiO}_{2}, \mathrm{MnO}$, and $\mathrm{Na}_{2} \mathrm{O}$ are usually less than $1 \%$ and are regarded as constituting impurities (Lippman, 1973). The average $\mathrm{CaCO}_{3}$ for Ubo and Ikpeshi Marble are $92.51 \%$ and $97.40 \%$ respectively. The average $\mathrm{MgCO}_{3}$ content calculated for Ubo and Ikpeshi Marble are $6.33 \%$ and $1.03 \%$ respectively. A plot of the $\%$ weight of $\mathrm{CaCO}_{3}, \mathrm{MgCO}_{3}$ and others on a triangular diagram of classification of carbonate rocks adopted from (Carr and Ronney, 1983), shows that the two marble bodies falls within the pure calcite marble (E) and pure calcite-dolomite marble (D)field.

The mean $\mathrm{CaO}$ and $\mathrm{MgO}$ content of $51.97 \%$ and $3.0 \%$ for Ubo marble and $54.73 \%$ and $0.49 \%$ for Ikpeshi marble samples are comparable to those of typical calcitic marbles (Table 3). They have a relatively low $\mathrm{MgO}$ content. Thus the two masses of Ubo and Ikpeshi marble are calcitic marble containing dolomite crystals in varying proportion.

The Ubo and Ikpeshi marbles have been preliminary investigated from the geochemical composition. The results obtained shows that $\mathrm{CaO}$ range from 54.01$55.80 \%$ in Ikpeshi marble and $48.50-55.90 \%$ in Ubo marbles. The percentage of $\mathrm{MgO}$ in both locations are low, $\mathrm{MgO}$ range from $0.33-1.18 \mathrm{wt} \%$ in Ikpeshi marble and $0.84-7.70 \mathrm{wt} \%$ in Ubo marble and has an average mean of $0.49 \%$ and $3.0 \%$. The percentage of $\mathrm{Al}_{2} \mathrm{O}_{3}$ in both locations are also low, $\mathrm{Al}_{2} \mathrm{O}_{3}$ range from 0.06$0.52 \mathrm{wt} \%$ in Ikpeshi marble and $0.08-2.18 \mathrm{wt} \%$, in Ubo marbles. $\mathrm{SiO}_{2}$ in Ikpeshi marble range from 0.2.$0.91 \%$ while $0.07-1.47 \%$ in Ubo marble and has an average mean of $0.72 \%$ and $0.74 \%$ in Ubo marble, $\mathrm{Fe}_{2} \mathrm{O}_{3}$ ranges from $0.18-0.34 \mathrm{wt} \%$ in Ikpeshi marble and $0.04-1.92 \mathrm{wt} \%$ in Ubo marble and has a mean chemical composition of $0.25 \%$ in Ikpeshi marble and $0.34 \%$ in Ubo marble. The major element composition of the Ubo and Ikpeshi marble shows it is similar in composition to calcitic marble (Okunlola, 2001).

Conclusion: The major element composition of the Ubo and Ikpeshi marble shows it is similar in composition to calcitic marble and the similarity between the two masses of the marble is apparent from the similarity in trend in the geochemical plots of the major element oxides. Most of the major element oxides show a negative correlation relative to $\mathrm{SiO}_{2}$, this probably reflects the admixture of the carbonates with chert.

The mean chemical composition of the total alkalis $\left(\mathrm{Na}_{2} \mathrm{O}+\mathrm{K}_{2} \mathrm{O}\right)$ in the two marble bodies is less than $2 \%$. From the above, low value of silica content and alkali element indicates that there was little influx of sediment into the Basin and salty brine water and high value of $\mathrm{CaO}$ indicates that the Basin was formed in a shallow marine environment with high precipitation of $\mathrm{CaO}$ and low $\mathrm{MgO}$ translate low dolomite content and low $\mathrm{Al}_{2} \mathrm{O}_{3}$ indicate low energy environment in the Basin. It can also be said that the Ikpeshi and Ubo marble deposits serves as a source of raw material for industries and also suitable for cement prouction due to its relatively low value of silica and high value of $\mathrm{CaO}$. 


\section{REFERENCES}

Bolarinwa, AT; Idakwo, SO (2013). Evaluation of Albian Limestone Exposed at Dangote Cement Quarry, Ise- kucha near yandev, North Central Nigeria. International Journal of Science and Technology Vol.2 No. 12, pp 847-856

Boynton, RS (1980). Chemistry and Technology of Lime and Limestone. $2^{\text {nd }}$ edition John Wiley USA, 578p

Carr, DD; Rooney, LF(1983). Limestone and Dolomite. In Lefond, S.Y. (Ed.) Industrial Minerals and Rocks ( $5^{\text {th }}$ edition). New York: (America Inst. Met. And Petr. Engr. Inc.) pp. 833868

Chave, KE (1954). Aspect of the Biogeochemistry of Magnesium in Calcareous Marine Organisms. Journal of Geol. Vol 62:, pp 266-283

Clarke, FN (1924). The Data of Geochemistry (2nded.)Washington Government Printing Office, $782 \mathrm{p}$

Dada, SS; Birck, JL; Lancelot, JR; Rahaman, MA (1993). International Colloquim on African Geology, Mbabane, Swaziland, pp 97-100.

Davou, DD; Ashano, EC (2009). The Chemical Characteristics of the Marble Deposits East of Federal Capital Territory (FCT), Nigeria. Global Journal of Geological Sciences, 7(2), pp 189-198.

Dunham, RJ (1962). Classification of Carbonate Rocks according to Depositional Texture, In classification of Carbonate Rocks (Ed by W.E. Ham), pp. 108-121, Mem, AAPG.

Emofurieta, WO ; Ekuajemi, VO (1995). The usual Compositional Disparities between the Samples. Imposed corresponding chem search. Journal 6(1), pp 38-45

Fruth, L; Scherreiks, R (1975). On Faecies and Geochemical Correlations in the Upper Hauptdolom of the Eastern Lechter Aips, pp 2745

Howrie, DG; Walden, I; John F (1982). Modern Lime Burning Plant at Shapefell Quarry, Management and Products Deposits, pp 163-171.

Land, LS; Hopp, GK (1973). Hydrothermal Dolomitization and Recrystallization of Dolomite Breccias from the Miocene Monterey Formation.
Journal of Sedimentary Petroleum Vol 43, pp 614-617.

Lipmann, F (1973). Sedimentary Carbonate Minerals. Springer verlag. Berlin Heidelberg. New York, 229 p.

Madhavaraju, J; Ramasamy, S (1999). Rare Earth Elements in Limestones of Kallankurichchi Formation of Ariyalur group, Tiruchirapalli Cretaceous Tamill Nadu. Journal of the Geological Society of India, pp 291-301.

Mason, B (1966). Principles of Geochemistry. $4^{\text {th }}$ edition, John Wiley andSons, New York.

Munyanyiwa, H; Hanson, RE (1988). Geochemistry of Marbles and Calc-Silicate Rocks in the Pan Africa Belt, Zambia: Precambrian Research, Vol 38, pp 177-200

Obasi, RA; Anike, OL (2012). Geochemical and Economic Application of Marble from Igarra and Ikpeshi areas, S.W. Nigeria. International Journal of Engineering and Technology, Ijet, vol, 2, pp 1723-1727.m

Obasi, RA; Ogungbuyi, PI (2013). Petrogenetic and Distribution of Trace and Rare Earth Elements in the Marble from Igarra Area, Southwest Nigeria. Jour. Of Env. Sci. Vol 3(13), pp $66-77$.

Okunlola, OA (2001). Geological and Compositional Investigation of Precambrian marble bodies and Associated Rocks in Burum and Jakura areas, Nigeria., Ph.D. Thesis University of Ibadan, Nigeria, 193p.

Onimisi, M; Obaje, NG; Daniel A (2013). Geochemical and petrogenetic characteristics of the marble deposits in Itobe area, Kogi State. pp $7-10$

Philips, RI; Folorunso, AF; Oluwalaanu, JA (2009). Evaluation of Turonian Limestone Formation Exposed at Nigercem-Quarry Nkalagu, Southeastern Nigeria. A Geochemical Approach. Pacific Journal of Science and Technology. Vol 10 (2) pp 763-771.

Tegure, AE (1989). The geology and petrogenesis of part of Muro hills marble deposit; Sheet 228 (Katakwa), Nigeria; M.sc thesis, University of Jos (Unpublished) $117 \mathrm{p}$. 